\title{
Energy consumption analysis between water and air quenching of fibers at meltblowing die exit
}

\begin{abstract}
The primary polymer resin for a meltblowing process is polypropylene (PP). The PP fibers have two basic crystalline forms, $1 \beta$-form (hexagonal), and $\gamma$ form (monoclinic). Quenching of the fibers improves the fabric properties because of the change of the PP crystalline form. There are two ways of quenching the fibers, waterand air-quenching. To their respective optimization, both achieve similar results in the fabric improvement. This paper quantitatively calculates the difference in energy consumption between the two quenching methods.
\end{abstract}

Keywords: meltblowing, polypropylene, microfibers, water quenching, air quenching, crystalline, $\beta$-form, $\gamma$-form

\author{
Volume 4 Issue 3 - 2018
}

\section{Peter PTsai}

Textiles and Nonwovens Development Center, The University of Tennessee, USA

Correspondence: Peter PTsai, Textiles and Nonwovens Development Center, The University of Tennessee, Knoxville, Tennessee, USA, Email ptsai@utk.edu

Received: January 04, 2018 | Published: May 0I, 2018

\section{Introduction}

Meltblowing (MB) is a process to make microfibers directly from polymer chips through extruding, fiber spinning, and laying down of the fibers on a collector. ${ }^{2}$ The process has been widely investigated at the Textiles and Nonwovens Development Center (TANDEC) ${ }^{3}$ at the University of Tennessee from 1980s to the present for more than 30 years. In one of their studies, it was observed that water quenching of the fibers at the die exit improves the fiber and the web properties such as the increase of the fiber strength, the decrease of shot formation, the increase of polymeric output, and the improvement of the fragility of the fabric ${ }^{4}$ due to the difference in the crystalline structure with and without the quenching of the fibers. The former is a $\beta$-form while the latter is a $\gamma$-form. There are two ways to quench the fibers, i.e., air- and water-quenching.

\section{Calculations}

The equations of energy consumption using air cooling and water quenching were presented in ATNT Conference. ${ }^{5}$

The primary air flow rate is usually $1,000 \mathrm{Nm}^{3} / \mathrm{hr}$ for PP meltblowing per meter of spinning width. In this case, the primary air velocity at the die exit is $230 \mathrm{~m} / \mathrm{s}$ given that the die nominal width of $1.2 \mathrm{~m}$ and the face gap is $1 \mathrm{~mm}$. The primary air temperature is normally $5-10^{\circ} \mathrm{C}$ higher than the polymer melt temperature to keep the die tip temperature equivalent to the die body. The energy required to heat the air temperature from $32 \mathrm{C}$ to $280^{\circ} \mathrm{C}$ is $80.6 \mathrm{KW}$ based on the air specific heat of $1.007 \mathrm{KJ} / \mathrm{Kg} . \mathrm{K}$ and the air density of $1.1614 \mathrm{Kg} /$ $\mathrm{m}^{3}$ at $300 \mathrm{~K}$.

\section{Cooling air quenching system}

The cooling air flow rate is basically from four to 10 times that of the primary air depending on the primary air velocity according to the aerodynamic theory. Cold air at $12^{\circ} \mathrm{C}$ is usually employed to quench the fibers. Using seven times of the primary air flow for the cooling air, the energy to cool the air of $7,000 \mathrm{Nm}^{3} / \mathrm{hr}$ from $32^{\circ} \mathrm{C}$, an example, to $12^{\circ} \mathrm{C}$ is $45.5 \mathrm{KJ} / \mathrm{s}$, which is $\$ 4.75 / \mathrm{hr}$ at $\$ 0.105 / \mathrm{KW} . \mathrm{hr}$ in Knoxville. A blower of $50 \mathrm{KW}$, which is $\$ 5.25 / \mathrm{hr}$, is required to blow the cooling. Therefore, the total cost of cooling air quenching is $\$ 240 /$ meter/day by assuming $100 \%$ efficiency of cooling and insulating system.
As shown in Figure 1 in the following section for a water quenching system, an air quenching system using air slots is installed on both sides of fiber stream.

\section{Water quenching system}

It is critical to control the water amount and the water droplet size to effectively quench the fibers while they are completely dehydrogenated before winding. The amount of water required to quench the fibers is $0.4-0.8$ times that of the polymeric mass depending on the polymeric throughput. The commonly industrial polymeric throughput is $0.4 \mathrm{~g} / \mathrm{h} / \mathrm{m}$ (gram per hole per minute) and the whole density is 35 holes/in. The polymeric throughput is thus $34 \mathrm{Kg} /$ $\mathrm{hr}$ for one meter wide die. Therefore, the required water amount to quench the fibers is $20 \mathrm{Kg} / \mathrm{hr}$ for a water/polymer mass ratio of 0.6 . The cost of water is $\$ 0.43 /$ day based on $\$ 7.15 / 2,000$ gallons of water in Knoxville.

A horse power of five is used in making the water droplets and in spraying them onto the fibers. The wattage of a five HP is $3.73 \mathrm{KW}$, which is $\$ 0.105 / \mathrm{KW} . \mathrm{hr}$ or $\$ 9.4 /$ day. Therefore, the total cost of water quenching is $\$ 1.83 /$ meter/day.

Figure 1 below shows a horizontal water quenching system at a vertical meltblowing system.

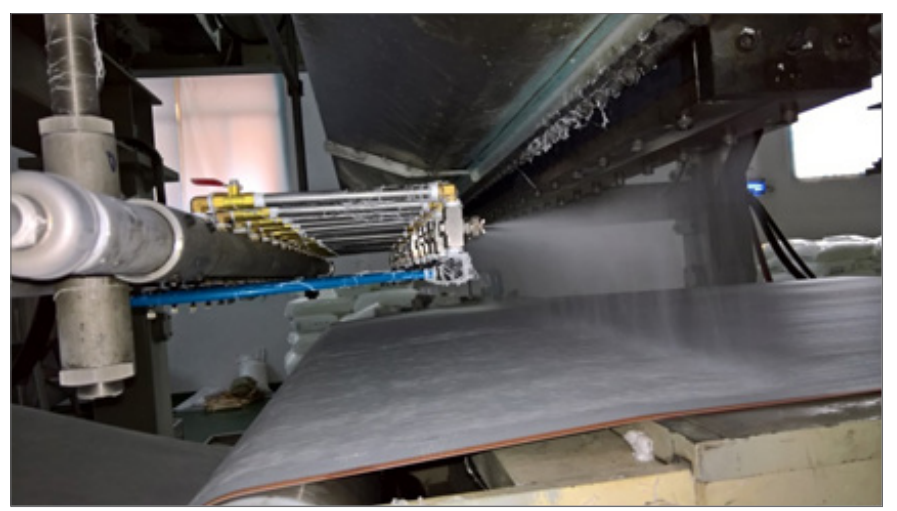

Figure I A water quenching system. 


\section{Theoretical discussion of Energy to cool the PP melt, and the water evaporation heat}

The specific heat of PP in solid state is $1.92 \mathrm{KJ} / \mathrm{Kg} . \mathrm{K}$, in melt state is $2.43 \mathrm{KJ} / \mathrm{Kg} . \mathrm{K}$. The PP fusion energy is around $90-100 \mathrm{KJ} / \mathrm{Kg}$ depending on its crystanillity. The total heat released from $34 \mathrm{Kg} / \mathrm{hr}$ PP melt at $260^{\circ} \mathrm{C}$ to $25^{\circ} \mathrm{C}$ is $19,992 \mathrm{KJ} / \mathrm{hr}$.

The heat to evaporate the $20 \mathrm{Kg} / \mathrm{hr}$ water from $18^{\circ} \mathrm{C}$ to $100^{\circ} \mathrm{C}$ vapor is $53,086 \mathrm{KJ} / \mathrm{hr}$ by taking the specific heat of water as $4.18 \mathrm{KJ} / \mathrm{Kg} . \mathrm{K}$ and the sublimation heat of water as $2,253 \mathrm{KJ} / \mathrm{Kg}$. Theoretically, from the above calculations, water is sufficient to quench the fibers.

\section{Conclusion}

To achieve the same results in improving the fabric properties, the energy cost of using water quenching is much less than that of using cooling air quenching, $\$ 1.83 / \mathrm{m} /$ day vs. $\$ 240 / \mathrm{m} /$ day. Water quenching is an inexpensive and a power way to quench the fibers.

\section{Acknowledgements}

None

\section{Conflict of interest}

Authors declare there is no conflict of interest in publishing the article.

\section{References}

1. Jones AT, Aizlewood JM, Beckett DR. Crystalline Forms of Isotactic Polypropylene. Macromolecular Chem \& Phys. 1964;75(1):134-158.

2. Vangas E. Meltblown Technology Today. San Francisco: Miller Freeman Publications; 1989.

3. Textiles and Nonwoven Development Center (TANDEC). Knoxville: The University of Tennessee.

4. Tsai P, Wadsworth L, Richeson G. Meltblown Web Properties Improved by Water Spraying the Fibers Near the Die Exit. Proc SPE ANTEC.1995;53(2): 1770-1775.

5. Tsai P. Optimization of the Meltblowing Process Design. Advances in Textiles and Machinery and Nonwoven and Technical Textiles, Coimbatore: ATNT-2008; 2008. 